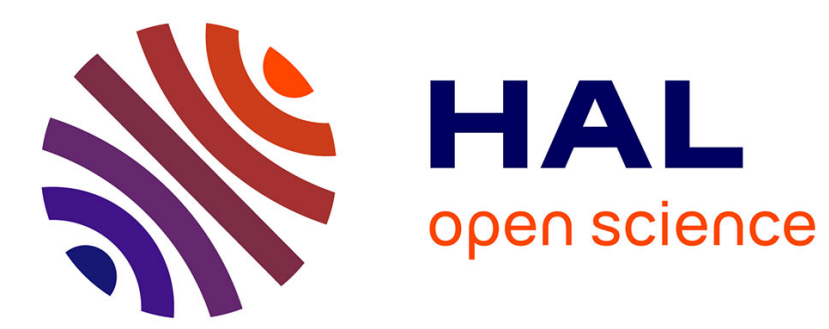

\title{
What Happiness???...!
}

Cecile Brehat, Florence Becker, Marie-Paule Chevalerias, Brigitte Hahusseau, Aurélie Nicodème, Martine Spiess, Anne Thevenot

\section{To cite this version:}

Cecile Brehat, Florence Becker, Marie-Paule Chevalerias, Brigitte Hahusseau, Aurélie Nicodème, et al.. What Happiness???...!. Recherches en psychanalyse, 2019, №27 (1), pp.37a. 10.3917/rep1.027.0037a . hal-03022789

\section{HAL Id: hal-03022789 https://hal.science/hal-03022789}

Submitted on 24 Nov 2020

HAL is a multi-disciplinary open access archive for the deposit and dissemination of scientific research documents, whether they are published or not. The documents may come from teaching and research institutions in France or abroad, or from public or private research centers.
L'archive ouverte pluridisciplinaire HAL, est destinée au dépôt et à la diffusion de documents scientifiques de niveau recherche, publiés ou non, émanant des établissements d'enseignement et de recherche français ou étrangers, des laboratoires publics ou privés. 
Cécile Bréhat, Florence Becker, Marie-Paule Chevalérias, Brigitte Hahusseau, Aurélie Nicodème, Martine Spiess, Anne Thévenot,

Translation Ubiqus Traduction

"What happiness?... !"

\section{An innovative experience in perinatal group support}

\section{Résumé}

Cet article vise à interroger l'accompagnement actuel en périnatalité et à éclairer ce qui l'ordonne dans le contexte et le lien social moderne. En le rapportant à son évolution depuis la moitié du $20^{\text {ème }}$ siècle, nous nous sommes attachés à repérer ce qu'aujourd'hui la notion d'accompagnement recouvre. Cette étude permet de constater qu'elle est organisée par les normes d'autonomie et de responsabilisation de soi, et des valeurs d'évaluation, de contrôle et d'éducation. Les dispositifs mis en place par les politiques publiques actuelles dans les temps périnataux qui visent à accompagner l'apprentissage de bonnes pratiques au regard des normes établies, écarteraient le travail d'élaboration subjective inhérent à l'arrivée d'un enfant. Nous exposons ici comment une expérience novatrice originale d'accompagnement groupal dans le temps du post-partum a été pensée. Elle est évoquée pour montrer comment une autre manière d'accompagner ces temps d'accueil de l'enfant et d'accès à la parentalité peut exister en mettant l'écoute de la subjectivité au cœur du dispositif. Mise en place, modalités de fonctionnement et visées sont approfondies. Les concepts psychanalytiques de contenance, de transmission et d'identification mis en mouvement par le dispositif groupal sont discutés en défendant l'hypothèse qu'ils participeraient à la construction du maternel et des liens précoces à l'enfant.

\footnotetext{
Abstract

This article aims to question the current support in the perinatal period and to highlight its organisation while considering the context and modern society. Since its evolution from the
} 
mid-20th century, we have tried to identify to what the current notion of support corresponds. This study shows that it is organised by rules of autonomy and empowerment of the ego, and by values of evaluation, control and education. The measures implemented by current public policies in the perinatal period, which aim to encourage the learning of good practices with respect to established standards, prevent the subjective processing work inherent on the arrival of a child. Here, we explain how an original and innovative group support experience in the postpartum period was conceived. This is described to demonstrate that there can be another way to guide the reception of the child and access to parenthood by focusing subjectivity on the centre of the group. Implementation, operational procedures and objectives are examined in depth. The psychoanalytic concepts of containment, transmission and identification activated by the group are discussed in defence of the hypothesis that they would participate in the construction of maternal and early bonds with the child.

\section{Mots-clés}

Accompagnement - Politiques publiques - Post-partum immédiat - Subjectivité - Dispositif groupal

\section{Keywords}

Support - Public policies - Postpartum period - Subjectivity - Group process 


\section{Introduction}

In the current French context, public policies in perinatal care aim to provide support to pregnant women with the purpose of promoting good child development through the transmission of good practice recommendations. Despite the establishment of networks of healthcare professionals, listening to mothers in the perinatal period in a clinical setting reveals a feeling of loneliness, which raises the question of the effect of medico-social practices on the psychological experience of motherhood. From this observation, rethinking the support system in the perinatal period seemed necessary. While attention to the newborn is paramount in current systems, it is nevertheless necessary to consider that constructing the maternal bond, indispensable to the child, cannot be reduced to socially expected behaviours. It entails a psychological upheaval that demands to be received. This article aims to present how, in the context of a maternity department, we, as a clinical psychologists, conceived an innovative perinatal group support experience. After establishing the notion of support from a conceptual and historical point of view by showing how social discourse is linked to care systems, we present how we have animated for the last five years the parent-and-baby support group. This clinical practice, in reference to psychologically analytical theoretical concepts, led us to identify the importance of mobilising the containment and transmission functions generated by this group and its effects on constructing the maternal bond.

\section{Support: its context, its aims}

Support currently groups many practices as therapeutic, educational and social support. This term has become generic since the late 1970s, and has invaded most professional fields at the pace of change in our contemporary world (Peny, 2006). Supporting practices refer to systems 
focused on the individual in line with societal values based on individualism, autonomy and self-empowerment norms, and the imperative of performance and efficiency (Neyrand, 2011). Support in its most diversified modes constitutes a form of regulation or adaptation giving primacy to the concepts of individualised trajectories, motivations and individual resources. It seems very difficult clear up the confusion generated by this term as it covers various approaches, such as coaching, advice, and other procedures or support relations. We must therefore be careful to "identify where support is needed and for what reason" (Paul, 2012, p.13). In addition to its various forms, it can be seen as a mechanism for implementing a common project co-constructed between a person and a professional. However, if the aim of a treatment for example is formulated as being common by both partners in the relationship, these practices are guided by goals of patient autonomy and self-determination, thus engaging the patients' responsibility in their future. Valuation, optimisation and encouragement integrated into the care relationship are linked to the obligation to render the efforts made profitable, given the economic realism (Rossi, 2009) of which they are part. Gori (2009) showed that coaching as a support method is a new means of social control and standardisation that neglects the complexity of the human psyche in favour of the person's "behavioural profitability" (Gori, 2009, p. 242). This paradoxical approach aimed at both taking into account individual freedom and consent to "autonomy on command" (Paul, 2012, p. 14) questions treatment ethics. It blurs what subjects say and what is heard by professionals, who actively guide them for their own good.

Perinatal support: a story of discourse and groups

\section{1 - From the development of knowledge to nurturing the mother-child bond}


Psychiatric knowledge built up in the $19^{\text {th }}$ century listed the mental disorders that can occur in pregnant women and recognised the possible madness of childbirth through the work of Esquirol (1819) and his student Marcé (1838), now considered a pioneer of perinatal psychopathology. It was only around the mid- $20^{\text {th }}$ century thanks to the contributions of psychoanalysis that knowledge of maternal pathologies and their impact on the quality of the early maternal bond developed. At the end of the Second World War, the prevalence of the mother-child relationship was recognised, as was the importance of the baby's emotional and relational life. In 1956, Winnicott described "the primary maternal concern" and highlighted normal maternal ambivalence. At that time, the notion of a deficiency in maternal care inspired Aubry and Spitz's work on hospitalism and anaclitic depression and Bowlby's work, which, supported by behavioural and ethological references, built a theory of attachment. However, Lebovici pointed out a few years later that this approach did not take into account the fantastical and unconscious interactions at work in the early relationship with the child. From the 1980s, the various actors involved in perinatal care questioned the complexity of this clinical approach and their professional positions in a context of pregnancy and birth medicalisation. They focused on the psychic dimension of motherhood and supported a human approach to giving birth to a child, reinforced by "The Newborn Notebook", which is the result of the reflection of the Group for Research and Studies on the Newborn. Dolto is thus a major reference promoting respect for the person, in this case the child, and focusing on the prevention of early relational disorders. The interest shown in the child and the investment in him/her, the acquired knowledge about the baby's skills and his/her cognitive and affective abilities contribute to placing emphasis on the conditions necessary for his/her development and fulfilment by highlighting the importance of the quality of the parent/child interactions in the child's psychological construction (Müller- Nix, Borghini, 2009; Pierrehumbert, 2003). Today, focus on Golse's work (2004) attempts to build a bridge between an attachment theory and 
psychoanalysis. However, despite these studies, accumulated knowledge has gradually transformed the care relationship and shifted the intervention of professionals towards expertise. Recommendations and prescriptions today respond to learning what is "good" parenting through a parenting education programme. The resulting objectification covers the recognised psychological challenges of motherhood and fatherhood and models, far from a clinical parental relationship, public prevention and control policies in the perinatal field.

\section{2 - Sources of the notion of perinatal support: prevalence of the medical discourse at the centre of public health policies}

Analysis of the evolution of health education policies shows how the notion of support emerges in care. According to Tillard (2007), the creation of health medicine in 1942 responded to a new movement: doctors no longer care only for the sick, but for the general health of everyone. In the logic of disease prevention, public and political discourse took hygiene and morality into account, and the notion of happiness was then associated with giving birth to healthy babies. Promotion of this idealisation justified medical supervision. In this movement, the Order of 2 November 1945 created the Maternal and Child Protection system (PMI). Its primary objective was to combat infant mortality and to protect pregnant women, young mothers and children up to their sixth birthday. The law of 18 December $1989^{1}$ redefined and extended the PMI's emission to the promotion of family health and the identification and support of vulnerable persons. The decline in maternal and infant mortality made it possible to focus on the importance of the mental life of babies and young children in relation to advances in research on child development and psychology. At the same time, advances in obstetric medicine

Art L 2111-1, L 2112-2 and L 226-1 to 11 of the Public Health Code 
gradually led to the medicalisation of pregnancy, the course of which is marked by different examinations (three ultrasounds and screening for trisomy 21). Taken from the perspective of assessing the health of the baby, the body of the pregnant woman is objectified: "the exclusion of women as subjects of pregnancy reflects a shift from competence to the grip and omnipotence of the medical discourse" (Spiess, 1999, p. 44). The subjectivity of the maternity experience may therefore be challenged by the effects of encountering the medicalisation of perinatal care.

\section{3 - Support with prevention and education}

Mental health prevention was defined by Noel and Soulé (1985) based on risk factors by distinguishing three types of prevention: primary, secondary and tertiary, previously defined by the WHO according to the epidemiological model of the medical world. However, a few years before, Dolto designed an original early preventive device: the "Green House", a transitional space between the family home and the nursery or kindergarten. "Neither a crèche, nor a day care centre, nor a care centre, but a child-friendly centre where mothers and fathers, grandparents, parents, nannies and baby walkers are welcomed... and where their little ones can meet their loved ones. Pregnant women and their companions are also welcome" (Dolto, 1985 p. 403). This form of prevention, which is still topical, aimed to shed light on the way in which parents represent the child during foetal life and interact with him/her from pregnancy to the first years of life in order to unravel any mild symptomatology linked to relational dysfunctions. This concept of support was already proving to be very innovative in the way in which the socialisation system and its aim were conceived, by offering care to babies and their parents from birth and before entering into a collective structure. Primary prevention, as pointed out by Missonnier (2001), should reflect inthe attention paid to the benevolent reception of the parents' questions. This support was the foundation for "all-out" institutional prevention of signs of 
parental vulnerability and early interactive disharmonies. Such concern for preventive action through medico-social management and directed supervision of pregnancy and birth is seen in the Perinatal Plan (2005-2007), with in particular the systematic proposal of the early prenatal interview at the fourth month of pregnancy. This system, which is inseparable from raising awareness and involving professionals, cannot be excluded from network of work (Dugnat, 2012), which aims to have a preventive effect with regards to the baby by paying particular attention to early parenting. Focused for a long time on the mother, the quality of the mother's relationship with the child's father is taken into account more. This network of clinical work, defined by Molénat (2016), emphasises, among other things, respect for parental subjectivity, the need to differentiate the places of different professionals as well as to strengthen their ties, and the refusal of screening in the name of the medical or social order. However, the best practice guidelines published for parents (blue booklet, maternity booklet) show a shift in this preventive aim to a predictive dimension that risks locking parents into a normative and culpable parenting pattern. Support for the perinatal period is now becoming systematic: assessment, monitoring and education are the objectives of these political guidelines. The pitfall of this approach to prevention would be to induce. Currently, support in early postnatal care is limited to consultation with a doctor or midwife six weeks after delivery, consultations with the paediatrician and possibly breastfeeding consultations. Other care and prevention schemes, such as PMI and child-friendly centres (LAPE) would be more invested with a view to "good" child development.

We also felt it was important to think about other forms of support that articulate the medicosocial in the field of subjectivity, in other words to promote institutional frameworks and mechanisms conducive to the care of parents enabling the expression and symbolisation of the psychological transformations that accompany the establishment of the first bonds with the child. It was with this in mind that a "parent-and-baby" group was founded in the maternity 
department.

\section{The parent-and-baby group as an original support mechanism}

In order to offer non-normative support while keeping as close as possible to parental concerns, for the last five years we have ran a parent-and-baby group for parents in a hospital centre. When they return home with their baby, they are informed by the care staff about this group, which we have intentionally called "What happiness???...!". They are given a brochure presenting the proposed objectives, date, place and themes. We opted for a light-hearted poster using a cartoon to suggest that you can take a step back from what you are experiencing; three question marks to question this idealism; three periods to reflect on it and talk about it; an exclamation mark to for good humour when faced with difficulties. The title and drawing have been designed to be open enough for everyone to understand. The group, which is simple in its form, immediately received the support of hospital department managers and that of the nursing team, who made sure that it was implemented.

\section{1- From the project to its completion}

Offering parents a place to meet during this vulnerable period after leaving the maternity seemed essential to us. Making it possible to return to the place of birth responds to a latent demand, that of creating continuity between the birth and their life as parents with the child. Some parents confirmed their expectation of a safe space: "Coming here is going back to the reassuring cocoon where he was born". A term often used, the "cocoon", seems to indicate that it is not only the birth of a child, but also that of his/her parents. "In the maternity, we are looked after, at home we realise it's our baby, that we don't have an answer to everything, that we are 
responsible for him and that's scary." In this post-birth period, parents are looking for references, beyond the "we" with which they define themselves, the appropriation of their identity, what the relationship with their child now involves and what renunciation involves. Fatigue and reorganisation of a daily life contribute to their strange disarray. Following the "Green House" model that Dolto defined as a place where everyone can rest and discuss with others, our aim is to offer a friendly and welcoming space, where everyone is free to come, where parents can relax, regain some security, and interact with others that are both similar and different.

\section{2- Presentation of the functioning}

This parent-and-baby group, led by a clinical psychologist and a childcare nurse, meets twice a month. A dozen mothers and fatherswith their infants are received. Parents and animators sit in a circle on rugs and cushions with their babies on their knees or in their arms or, for older children, in the play area in the centre of the group. The setting guarantees anonymity and free access. The parents with their baby present themselves briefly. Then, for about 1 hour and 30 minutes, they are invited to discuss a topic that will stimulate each person to ask questions. The themes are chosen for the interest they usually arouse among young parents during this period of the baby's first months of life: sleep, feeding, crying, etc. Others are suggested by parents, such as how to be both a mother and a woman, growing up with screens, family, etc. The dual training of the animators was designed to facilitate exchanges and enable them to build upon what the person speaking is saying to ask their own questions. We are not here to provide answers, but to propose a safe area that allows, through hearing the different viewpoints introduced by the professionals and members of the group, a shift from normative knowledge and to find though the experiences of each person, the necessary references for the appropriation 
of the relationship with their child.

\section{3- The group as a support for the subjective expression of "the future" parent}

The many bodily and psychological upheavals introduced or reactivated by the arrival of the child contribute to placing the post-birth period in a particular temporality, where the mother is generally completely focused on her baby, sometimes overwhelmed by him/her. For women and men becoming mothers and fathers, the arrival of the child is a reality test. They find themselves frequently helpless faced with the baby they are discovering and struggle with the psychological work going on inside them. A certain loneliness is inherent in this subjective journey. The expression of a sense of isolation, even distress, seems hardly verbalizable to the close entourage focused on this "wonderful baby". "You feel really alone at home, you wonder if you're the only ones living this - but who is there to talk to?" Being able to talk about their possible unhappiness, their ambivalence, their feelings of guilt, the vacillation of their identity in this experience of motherhood and fatherhood is fundamental in the construction of their paternal bond. Winnicott (1956), Bibring (1959), Benedeck (1959), Tustin (1972) and Racamier (1979) reported on the psychological pressure of a woman who has become a mother. This experience may provoke questions or even anxiety. However, a request for psychological care is rarely made because these difficulties are generally not related to any pathology and do not require a specialist consultation. Becoming a parent is a constructive process with a pace, a space and a time. The perinatal period is both a source of creativity and vulnerability. For us, the aim is to support these intrapsychic processes and to accompany "psychic childbirth" (Rochette, 2003, p: 97) by promoting the expression of words to describe the experience. However, social pressure, the idealisation of becoming a mother and often experienced relatives tend to make development processes difficult by denying that this period may be complex: "It 
is difficult to trust ourselves, we feel judged by the people around us who tell us what to do; we think that they have the experience and therefore that they know what to do, but we would ultimately like to listen to ourselves". In this space, it is then possible to address the gap between the imaginary baby and the real baby, and the feeling of strangeness or sometimes even unreality. The neutrality offered by the group allows mothers to open up at a time when they need time to talk. Indirectly, talking makes it possible to open up and express ambivalence, hatred and loneliness concerning the bond with the child: "I can't tell anyone around me that my baby annoys me, that sometimes I can't stand him when he's crying and that I'm tired."

\section{4- The group's containment role}

From the very first moments of group formation, shared defence mechanisms are established against archaic anxieties in a massive identification phenomenon. The group then becomes the place of transformation of psychic reality that is otherwise inaccessible. By its containment role, it acts as an envelope around non-mentalised raw elements and enables their metabolism (Kaës, 2005). It is a space where the complex experiences around the birth of a child, impulsive, violent, excessive discharges, are welcomed, expressed, contained and transformed by the group before being re-injected into the individual psyche: "Here, we are not judged, but listened to, we can express our doubts, our fears", "it was so unbearable to hear him crying that I walked out of the room; I felt an aggressiveness overflowing me and I was scared" and another mother replies "it feels good to hear that, I've already felt that". The common psychic space created makes it possible to manage the psychological organisation of each person and to revive the imaginary function, the capacity for reverie sometimes suspended in time after birth, predominant in the establishment of the maternal bond and so important in the emergence of the baby's psychological life. According to Mellier (2012, p. 225), the group participates in the 
development of the mother's capacity for reverie who, caught in the inter-subjective relationship with her baby, "attempts to approach empathically the baby's distress". Providing a maternal role: "a state of mind capable of accommodating the infant's projective identifications, whether they are perceived by him/her as good or bad" (Bion, 1962, p. 54), the group supports the mother's thinking in order to enable her, in turn, to provide a protective shield and to compensate for the baby's lack of thinking. Mellier differentiates the "containment function" from the "function to be contained" defined as "a position to be maintained so that a bond can be created, so that something can be tested, so that a task of attention can be carried out in intersubjectivity, while multiple realities heterogeneous to the psychic are summoned" (2005, p. 493). The process specific to this role is based on psychic work of differentiation, which it defines "as the psychic position to be adopted and implemented in the field, in intersubjectivity, to receive and transform very primitive suffering" (ibid., p. 247). The containment function is associated with the notion of psychological conflict in the sense that it makes it possible to encounter elements in the psyche that would otherwise remain undifferentiated. This is why the containment function that the group provides directly affects the construction of the baby's own thinking abilities.

\section{5- The group's transmission and identification function}

Currently, the private dimension of birth has overtaken its community dimension. Mothers often express feelings of loneliness, sometimes even evoking their distress: "There is panic when you leave the maternity ward; you feel guilty about crying when you know you should be swimming in happiness." In our system, this missing group dimension is reintroduced: leaving your home with your baby breaks the isolation. The group makes it possible to de-dramatise culpable situations by observing that others have experienced them or feel the same difficulties: "It's 
important not to be alone, locked in one-on-one with the baby; going out and meeting other parents, realising that others have also gone through the same thing, that it's completely normal" The group reassures, supports deviation from the norm, allows the expression of feelings and strengthens trust: "We have a lot of information and we no longer know what to believe. Here, we discover that we have the right to listen to each other and trust each other", "let's listen to our babies, we have the answers". But the group also makes it possible to think together about a subjective experience and not transmit knowledge in the light of what is normal socially. Each person will be able to learn from the experience of the others, and share something unique and common at the same time, which will reinforce the feeling of belonging to the "parents" group. "When I listen to you, I realise we're all going through the same ordeal with our beloved babies." Strong identification is made possible. In addition, the attention of others, empathy and support of others who have had previously the same experience encourage the search for our own answers, which helps build confidence in our own resources: "Sharing with you helps me hold on when I doubt everything." Babies frequently fall asleep in the arms of their calmer mothers, demonstrating physical and psychological relaxation. The words used at the end of the meetings are particularly strong: "We're going to survive", "It saved our lives", "It's a lifesaver to come here", "sharing is vital", "It's a breath of fresh air" or: "Luckily you [the group] are here, otherwise I'd feel like I'm going crazy." These expressions tell us how ordinary postbirth experiences can be intense, and difficult to bear and express without the support of a containment environment.

\section{6- Changes to the system}

Over time, we have received requests from many first-time pregnant women who want to 
participate in this group, saying they want to "know what's coming". Their observation, their attentive listening, but also their silence, which was sometimes surprising, led us to think that although this place is not suited to them, a space for expression is also necessary during the prenatal period. We also found that several women who came with their first baby returned when their second child was born. They stated immediately their desire to help and support new mothers who might be in the same distress as they were the first the time; thus they have a special place in the group. Their very maternal, protective and reassuring attitude invites young mothers to listen to each other and trust each other: "Nothing stays the same, everything changes, you will make it". None of them claims to know more that the others. The support of the group and especially the older members allows and encourages mothers to search for their own answers and build confidence in their own psychic resources. The constant increase in requests to participate in the group raises questions, beyond this one, about what is currently offered to pregnant women and young women who have given birth. In the same movement, it is no longer possible at present to participate in these groups due to the lack of time of maternity department professionals. A partnership has also been established with the PMI nursery nurses. This new collaboration could make it possible to think differently about prevention in these places and to develop parental representations guided by normative guides.

\section{Conclusion}

The group that we formed, initiated by clinical experience in the maternity department, revealed that at the heart of the words of parents and mothers in particular, lies the subjective expression of their psychological upheavals concerning the new reality experienced with their newborn 
child, and the need for them to question and express it. This group taught us the essential importance of listening to the expression of thoughts and feelings in postpartum support. This perhaps pushes back the medico-social discourse, viewed as an expert's discourse aimed solely at the baby's mental and somatic health. While knowledge from experts increasingly meets a "bulimic" search for guidance by young mothers (use of the Internet), it sidelines and complicates access to their own internal resources. However, construction of the maternal bond would be promoted more by the reception and transformation of what is subjectively experienced rather than by learning the good behaviour that makes it possible to be a responsible individual. However, Winnicott previously argued: "Mothers who have the capacity to provide good enough care can be better cared for by caring for them in a way that recognises the essential nature of their task. For mothers who do not have this in them, it is not by educating them that they will be able to do so" (1960, p: 371). One of the aims of this group is to help mothers find pleasure in looking after their child. At a lecture given to student nursery nurses, Winnicott said: "Prevention of psychiatric disorders is initially a matter of maternal care and of what a mother who is happy to look after her baby does naturally" (1966, p:31). This space for meeting and discussion facilitates the identification of the need for specialised consultations, if necessary. In our system, support is therefore neither therapy, nor education, control, help or suggestion, but support and encouragement of the expression of thoughts and feelings by recognising the psychological work that takes place during this sensitive period. The therapeutic value of the human bond lies in its ability to recognise otherness and respect its difference, and not in reference to a standard or values that refer to a moral that is inherently cyclical. Beyond good advice, good practices, and the social model that defines a good or bad parent, expression is liberated. The group, by its containment function and by its transmission function, allows each person to express his/her subjective dimension and imagination. Through the effect produced, this group constitutes a place of prevention (early relational disorders, postpartum 
depression) without this being its intended purpose (screening, identification).

\section{Declaration of interests}

The authors declare that they have no common interests.

\section{Bibliography}

Aubry, J. (1955). La carence de soins maternels, Paris, Centre international de l'enfance réédité en 1965 sous le titre Enfance abandonnée, Paris, Scarabéé \& Compagnie/A.M. Métaillé. Benedek, T. (1959). Parenthood as a developmental phase: a contribution to the libido theory. Journal of the american psychoanalytic association, 7, p. 389-417. Bernard-Chatelain, C. (2010), « Le forum de Maman Blues: prendre soin des mères en difficultés maternelles », L’information psychiatrique, 86, p. 771-776. 
Bibring, G.L. (1959). Some considerations of the psychological processes in pregnancy, The psychoanalytic study of the child, 14, p: 113-121.

Bion, W. (1962), Aux sources de l'expérience, Paris: PUF, 2003.

Bowlby, J. (1969) Attachement et perte, Paris: PUF, (3 tomes), Paris: PUF, Le Fil rouge, trad. française, 1978 et 1984.

Cramer, B., Palacio Espasa F., (1983), La pratique des psychothérapies mères-bébés. Études cliniques et techniques, Paris: Puf.

Dolto, F. (1985), La cause des enfants. Paris: Seuil.

Dugnat, M. (2012). Réseaux en périnatalité: les outils pratiques d'une prévention universelle prévenante ? Définitions, critiques et propositions, Spirale, 61, p:139-162.

Dugnat M., Gouzvinski F. (2016), Pour la santé mentale et la psychiatrie périnatale en France, Spirale, $78, \mathrm{p}: 33-44$.

Golse, B. (2004). La pulsion d'attachement, La psychiatrie de l'enfant, 47, p: 5-25.

Esquirol J.-E. (1819), De l'aliénation mentale des nouvelles accouchées et des nourrices, Mémoire.

Gori, R. (2009). Thérapies molles, pathologies flexibles et logique évaluative dans Fischman G., L'évaluation des psychothérapies et de la psychanalyse. Fondements et enjeux, p.239-257, Paris: Masson, 2009.

Kaës, R. (2005). La parole et le lien - Processus associatifs et travail psychique dans les groupes, Paris: Dunod.

Lebovici S. \& Stoléru S. (1983), Le nourrisson, sa mère et le psychanalyste. Les interactions précoces, Paris: Bayard, 1994.

Lecavelier N., (2004), Expérience groupale d'écoute et de suivi des familles, Spirale, 31, p.6170.

Marcé, L. V. (1858), Traité de la folie des femmes enceintes, des nouvelles accouchées et des 
nourrices, Paris: Baillières \& Fils, 2002.

Mellier, D. (2005), La fonction à contenir. Objet, processus, dispositif et cadre institutionnel, La psychiatrie de l'enfant, 48, p: 425-499.

Mellier, D. (2012), Souffrance, attention et processus de contenance chez le bébé, dans Mellier D., La vie psychique du bébé, p. 197-243, Paris: Dunod, 2012.

Missonnier, S. (2001), Le bébé, la maternité et la prévention, dans Delion P., Le bébé et ses institutions, p. 53-66, Toulouse: Erès, 2001.

Molénat, F. (2016), Naissances: pour une éthique de la prévention, Toulouse: Erès.

Müller- Nix C., Borghini A. (2009), Prématurité, vécu parental et relations parents/enfant: éléments cliniques et données de recherche, La psychiatrie de l'enfant, 52, p: 423-450.

Neyrand G. (1999), Savoirs et normes sociales en matière de petite enfance, Recherches et prévisions, 57, p. 3-15.

Neyrand, G. (2004), La dynamique d'un réseau de prévention psychique précoce. Résistances et perspectives, Revue française des affaires sociales, 1, p.103-125.

Neyrand, G. (2002), La prévention précoce, une démarche paradoxale, Dialogue, 157, p.3-13. Neyrand, G. (2011), De l'expert psychologue au parentalisme politique, les apories de la coéducation », Enfances \& Psy, 52, p.28-37.

Neyrand, G. (2013), Le soutien aux parents entre citoyenneté démocratique et individualisme néolibéral. Logique d'accompagnement et logique d'évaluation, Recherches familiales, 10, p. $49-56$.

Noël, J. \& Soulé, M. (1985). La prévention médico-sociale précoce dans Soulé M., Nouveau traité de psychiatrie de l'enfant et de l'adolescent, p: 3013-3042, Paris: PUF.

Paul, M. (2012). L'accompagnement comme posture professionnelle spécifique. L'exemple de l'éducation thérapeutique du patient, Recherche en soins infirmiers, 110, p. 13-20.

Peny, B. (2006). L'accompagnement dans la loi: entre rupture et continuité, Contraste, 24, p 
$153-165$

Pierrehumbert, B. (2003), Attachement et psychopathologie, Enfance, 55, p. 74-80.

Racamier, P.-C. (1979), La maternalité psychotique dans Racamier P. -C., De psychanalyse en psychiatrie, Etudes psychopathologiques, p.193-242, Paris: Payot et Rivages, 1998.

Rochette J., (2003), Le rituel, la mère et le bébé: un dispositif de soin en périnatalité, les groupes de présentation de bébés, Revue de psychothérapie psychanalytique de groupe, 40, p. 93-126. Rossi, I. (2009). L'accompagnement en médecine. Anthropologie d'une nécessité paradoxale. Pensée plurielle, 22, p.111-122.

Spiess, M. (1999). La mise en jeu du corps dans la maternité: contribution à la question de la féminité, Thèse de Psychologie, Strasbourg: Université Louis Pasteur, 266 p.

Spitz R. \& Wolf K.M. (1946), Anaclitic depression, Psychoanalytic study of the child NewYork: International Universities Press, 2, p.313-342.

Tillard, B. (2007). Quand la prévention sanitaire s'adresse aux parents et aux futurs parents. ethnographiques.org, 14

Tustin, F. (1972). Autisme et psychose de l'enfant, Paris: Seuil, 1975.

Winnicott, D.W. (1956). La préoccupation maternelle primaire dans Winnicott, D.W., De la pédiatrie à la psychanalyse, p: 285-291, Paris: Payot, Science de l'homme, 1989.

Winnicott, D.W. (1960), La théorie de la relation parent-nourrisson dans Winnicott, D.W., De la pédiatrie à la psychanalyse, p: 358-378, Paris: Payot, Science de l’homme, 1989.

Winnicott, D.W. (1966), « La mère ordinaire normalement dévouée » dans Winnicott, D.W, Le bébé et sa mère, p: 19-32, Payot, 1992. 